\title{
KERAGAAN WARNA DAN GENOTIPE CALON INDUK (F-0) IKAN CLOWN (Amphiprion sp.) STRAIN BLACK PERCULA
}

\author{
Ruby Vidia Kusumah", Anjang Bangun Prasetio, Eni Kusrini, Erma Primanita Hayuningtyas, \\ dan Sawung Cindelaras
}

Balai Penelitian dan Pengembangan Budidaya Ikan Hias

\begin{abstract}
ABSTRAK
Penelitian ini bertujuan mengkaji keragaan fenotipe warna tubuh dan genotipe calon induk (F-0) ikan clown (Amphiprion sp.) strain black percula. Sebanyak 36 ekor calon induk ikan clown black percula diperoleh dari populasi budidaya Balai Perikanan Budidaya Laut (BPBL) Ambon yang memiliki persentase penutupan hitam tinggi. Warna dianalisis dengan teknik analisis gambar digital menggunakan software ImageJ $1.50 f$. Gambar digital didokumentasikan menggunakan kamera Canon EOS 600D. Keragaan warna diamati menurut pola, persentase penutupan, dan jenis (profil) warna digital. Konversi nilai mean red $(\mathrm{R})$, mean green $(\mathrm{G})$, dan mean blue (B) menjadi nilai mean Hue (H), mean Saturation (S), dan mean Brightness (B) dilakukan dengan bantuan Color Picker (Foreground Color) pada software Adobe Photoshop versi 12.0 x64. Keragaan genotipe dianalisis dengan teknik RAPD. Heterozigositas dan persentase polimorfisme dikalkulasi menggunakan software TFPGA. Hasil penelitian menunjukkan bahwa calon induk ikan black percula generasi F-0 memiliki pola warna yang bervariasi dengan persentase penutupan warna hitam berkisar $47 \%-63 \%$. Jenis warna digital hitam dikarakterisasi oleh nilai H: $240^{\circ}-20^{\circ}$, S: 4\%-48\%, B: $10 \%-26 \%$; putih (H: $0^{\circ}-300$ -, S: $1 \%-7 \%$, B: 48\%-69\%); dan oranye (H: 15--25을 S: 73\%-91\%, B: 40\%-64\%). Analisis RAPD menunjukkan bahwa primer OPA18 menghasilkan tiga fragmen (berukuran 600-3.000 bp); OPZ-9 sebanyak lima fragmen (berukuran 500$2.500 \mathrm{bp}$ ); dan OPZ-5 sebanyak tiga fragmen (berukuran 400-3.000 bp). Heterozigositas dan persentase polimorfisme termasuk cukup tinggi, yakni 0,3060 dan $88 \%$. Untuk mendapatkan strain warna black percula yang diinginkan, tahap seleksi lebih lanjut diperlukan untuk meningkatkan persentase penutupan warna hitam, serta memperoleh pola warna putih unik.
\end{abstract}

KATA KUNCI: $\quad$ warna; gambar digital; genotipe; ikan clown; black percula; strain

ABSTRACT: Color and genotype performance of black percula strain clown fish (Amphiprion sp.) broodstock (F-0). By: Ruby Vidia Kusumah, Anjang Bangun Prasetio, Eni Kusrini, Erma Primanita Hayuningtyas, and Sawung Cindelaras

Our research aimed to assess the performance of body color and genotype of black percula strain of clownfish (Amphiprion sp.) broodstock F-0. A total of 36 samples of the black percula clown was obtained from the Institute for Mariculture (BPBL) Ambon which has the high percentage of black cover. Color analysis was performed using digital image analysis using ImageJ 1.50f. Digital images of broodstock was documented using Canon EOS 600D. Performance of color observed according to patterns, percentage of color coverage, and type of (profile) digital color. Conversion value of mean red $(R)$, mean green $(G)$, and mean blue $(B)$ was done by color picker (foreground color) in Adobe Photoshop software version $12.0 \times 64$. Genotypes performance analyzed with RAPD method. Heterozygosity and the degree of polymorphism was calculated by TFPGA software. The results showed that the broodstock of black percula has varies of the color patterns with the percentage cover of black color ranges from 47\%-63\%. Digital color of black profile was characterized by $\mathrm{H}: 240^{\circ}-20^{\circ}$, S: 4\%-48\%, B: 10\%-26\%; white (H: $0^{\circ}-300^{\circ}$, S: $1 \%-7 \%$, B: $48 \%-69 \%$ ); and orange (H: $\left.15^{\circ}-25^{\circ}, \mathrm{S}: 73 \%-91 \%, B: 40 \%-64 \%\right)$. RAPD analysis showed that primer OPA-18 produced three fragments (600-3,000 bp size), OPZ-9 produced five fragments (500-2,500 bp size), and OPZ-5 produced three fragments (4003,000 bp size). Heterozygosity and polymorphism were high as 0.3060 and $88 \%$. In order to obtain desired color strain of black percula, further selection process is necessary to increase the percentage of black color coverage and white color which is unique.

KEYWORDS: color; digital images; genotype; clownfish; black percula; strain

\# Korespondensi: Balai Penelitian dan Pengembangan

Budidaya Ikan Hias. Jl. Perikanan No. 13 Pancoran Mas,

Depok 16436, Indonesia. Tel.: + (021) 7530482

E-mail: rubyvkusumah@kkp.go.id 


\section{PENDAHULUAN}

Pasar ikan hias clown Pomacentridae telah jenuh dengan jenis warna dan pola warna normal yang sesuai dengan bentuk alaminya (wild-type) (komunikasi pribadi dengan CV Cahaya Baru, 2015). Untuk mengatasi hal tersebut para breeder di dunia telah mengembangkan berbagai jenis strain warna sesuai variasi jenis, persentase penutupan, dan pola warna yang terbentuk (Kusumah et al., 2015). Hingga saat ini berbagai strain warna ikan clown yang telah dihasilkan di antaranya strain platinum dan wyoming white yang didominasi warna putih, black clownfish yang didominasi warna hitam, naked yang didominasi warna oranye, dan caramel yang memiliki warna hitam yang pudar. Selain itu, berbagai variasi pola warna ikan clown juga telah diarahkan menjadi strain misbar, snowflake, picasso, daVinci, froshbite, domino, hingga nebula (ORA Farm, 2014a; 2014b; Barrier Reef Aquariums, 2016; Saltwater Fish, 2016). Variasi dalam suatu strain juga terus dikembangkan seperti halnya Sea \& Reef Aquaculture yang menemukan jenis strain warna baru yang hingga kini belum diberi nama (Sea \& Reef Aquaculture, 2016a). Di Indonesia sendiri, salah satu produsen/ breeder yang terus mengembangkan strain warna ikan clown adalah Bali Aquarich (www.bali-aquarich.com).

Berdasarkan komunikasi pribadi dengan CV. Cahaya Baru (2015), eksportir karang hias dan ikan hias laut, diketahui bahwa setiap strain warna ikan clown masih belum stabil. Dua atau lebih strain warna anakan yang berbeda dapat saja diperoleh dari hasil sortir dan pengelompokan berdasarkan jenis, persentase penutupan, dan pola warna dari pemijahan suatu strain induk yang sama. Dalam arti lain, pemijahan antara strain A dengan strain A tidak 100\% menghasilkan strain A saja melainkan juga terdapat berbagai variasi lainnya. Dengan banyaknya variasi ikan clown yang terbentuk dari hasil pemijahan atau perkawinan berbagai strain induk, kesempatan untuk membuat berbagai strain warna baru masih terbuka luas.

Kajian terhadap keragaan warna ikan clown penting dilakukan untuk mengetahui status dan profil warna terkini dari suatu populasi ikan yang dimiliki sebagai dasar pembentukan berbagai strain warna baru. Selain untuk menambah keragaman jenis dan strain (Permen KP, 2014) warna ikan clown yang ada, dari sisi bisnis, pembentukan berbagai strain baru juga dilakukan sebagai strategi pemasaran untuk memperkaya produk, meningkatkan daya tarik dan daya saing, serta menghindari kejenuhan di tingkat konsumen (Kusumah et al., 2015).
Black percula merupakan salah satu strain warna ikan clown Biak (Amphiprion percula) yang dikarakterisasi oleh penutupan warna hitam yang tinggi (dominan) pada permukaan tubuhnya. Strain ini memiliki harga jual yang lebih tinggi dibandingkan bentuk normalnya (wild-type). Menurut Saltwater Fish (2016), strain black percula dijual dengan harga US \$ 37,99 sedangkan bentuk normalnya seharga US \$ 25,99 . Selain warna, keragaan genotipe juga diamati untuk mengetahui variasi genetika tingkat molekuler populasi calon induk ikan clown strain black percula. Penelitian ini bertujuan untuk mengkaji keragaan fenotipe warna tubuh dan genotipe calon induk (F-0) ikan clown (Amphiprion sp.) strain black percula.

\section{BAHAN DAN METODE}

\section{Ikan Uji}

Sebanyak 36 individu ikan clown yang akan dijadikan sebagai calon induk yang akan digunakan dalam pembentukan strain black percula diperoleh dari populasi budidaya Balai Perikanan Budidaya Laut (BPBL), Ambon yang memiliki persentase penutupan hitam tinggi. Ukuran calon induk yang digunakan memiliki panjang rata-rata $4,2 \pm 0,3 \mathrm{~cm}$ dan bobot rata-rata $1,6 \pm 0,4 \mathrm{~g}$. Calon induk tersebut selanjutnya disebut sebagai ikan uji.

\section{Keragaan Fenotipe Warna}

Setiap jenis warna hitam, putih, dan oranye ikan clown diamati menurut pola, persentase penutupan, dan jenis warna sesuai Kusumah et al. (2015) dan Kusumah et al. (2011). Keragaan warna pada tubuh ikan clown didokumentasikan secara digital menggunakan kamera Canon EOS 600D berdasarkan modifikasi dari Kusumah et al. (2011).

\section{Pola warna}

Proses karakterisasi pola warna dianalisis langsung secara visual dengan bantuan tampilan layar komputer. Parameter yang diamati adalah: (i) bentuk strip warna hitam pada setiap bagian tubuh (terputus atau bergabung), (ii) bentuk normal dan tidak normal pada setiap strip warna putih (pelana dan terputus) (Kusumah et al., 2015), (iii) titik (spot) kemunculan warna oranye di seluruh bagian tubuh, serta (iv) kemunculan jenis warna hitam dan oranye pada sirip ekor (caudal). Variasi pola warna yang diperoleh $(w)$ pada setiap jenis warna, selanjutnya dihitung berdasarkan persentase kemunculannya pada setiap bagian atau total area tubuh menggunakan rumus: \% 


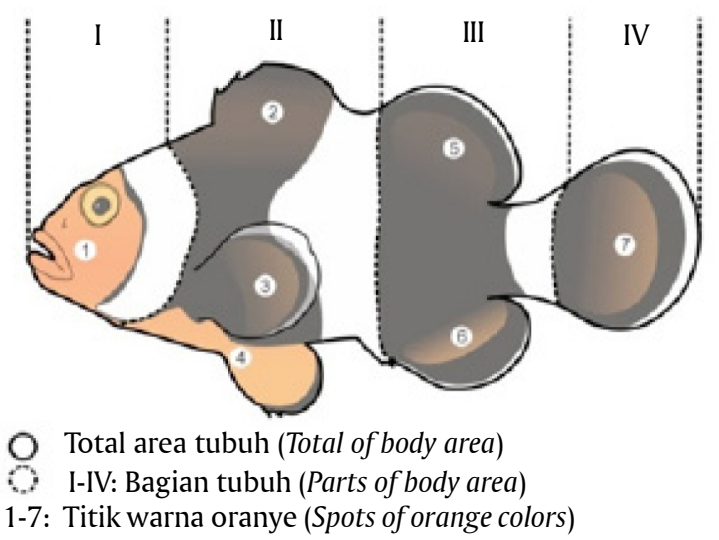

Gambar 1. Area dan titik pengamatan keragaan pola warna

Figure 1. Observed area and spots of color patterns performance

kemunculan karakter pola warna $w=$ (jumlah individu dengan kemunculan karakter pola warna $w$ / jumlah total sampel) $\mathrm{x} 100$. Area yang diamati ditunjukkan Gambar 1.

\section{Penutupan warna}

Persentase penutupan warna hitam, putih, dan oranye masing-masing diukur berdasarkan luasan pixel setiap jenis warna per luasan total permukaan tubuh ikan clown. Pengukuran setiap luasan pixel dilakukan menggunakan software Adobe Photoshop CS5 Extended versi 12.0 x64 berdasarkan Kusumah et al. (2015).

\section{Jenis warna}

Jenis warna digital hitam, oranye, dan putih ikan clown diamati berdasarkan Kusumah et al. (2015). Proses seleksi warna dilakukan dengan bantuan Freehand selections pada software ImageJ (Image Processing and Analysis in Java) versi 1.50f (Rasband, 2016). Kuantifikasi jenis warna dalam nilai mean red $(\mathrm{R})$, mean green $(\mathrm{G})$, dan mean blue (B) dilakukan menggunakan RGB Measure pada software yang sama. Konversi nilai R, G, dan B menjadi nilai mean Hue $(\mathrm{H})$, mean Saturation (S), dan mean Brightness (B) pada model warna HSB dilakukan dengan bantuan Color Picker (Foreground
Color) pada software Adobe Photoshop (Kusumah et al., 2015) atau tool konversi warna digital lainnya (Kusumah et al., 2011). Nilai yang dianalisis lebih lanjut adalah nilai digital $\mathrm{H}, \mathrm{S}$, dan $\mathrm{B}$.

\section{Keragaan Genotipe}

\section{Ekstraksi DNA}

Analisis genotipe dilakukan secara molekuler dengan metode RAPD (Random Amplified Polymorphic $D N A$ ). DNA genom diekstraksi dari sirip menggunakan GeneJET Genomic DNA Purification Kit (Thermo Scientific) dengan prosedur sesuai manual.

\section{Amplifikasi}

Amplifikasi dilakukan dengan teknik RAPD pada mesin PCR thermocycler gradient (Applied Biosystems). Program PCR terdiri atas denaturasi awal pada suhu $94^{\circ} \mathrm{C}$ selama 2 menit, 35 siklus terdiri atas denaturasi 94 $\mathrm{C}$ selama 1 menit, annealing sesuai temperature Melting (TM) primer (Tabel 1) selama 1 menit, dan extension $72^{\circ} \mathrm{C}$ selama 2 menit, dan diakhiri dengan 1 siklus extension pada $72^{\circ} \mathrm{C}$ selama 7 menit. Komposisi pereaksi terdiri atas 12,5 $\mu \mathrm{L}$ Dream taq Master Mix 2x (Thermo Scientific), $1 \mu \mathrm{L}$ primer RAPD, $3 \mu \mathrm{L}$ DNA, kemudian ditambahkan nuclease free water sampai

Tabel 1. Urutan basa Primer RAPD

Table 1. Sequence parameters of RAPD primers

\begin{tabular}{lcccc}
\hline $\begin{array}{c}\text { Kode primer } \\
\text { Primer code }\end{array}$ & $\begin{array}{c}\text { Urutan basa (5' - 3') } \\
\text { Sequence base (5'-3') }\end{array}$ & $\begin{array}{c}\text { Panjang nukleotida } \\
\text { Nucleotide length }\end{array}$ & $\begin{array}{c}\text { G+C } \\
\text { (\%) }\end{array}$ & $\begin{array}{c}\text { Suhu penempelan }\left({ }^{\circ} \mathrm{C}\right) \\
\text { Annealing temperature }\left({ }^{\circ} \mathrm{C}\right)\end{array}$ \\
\hline OPA-18 & AGG TGA CCG T & 10-mer & 60 & 36.2 \\
OPZ-5 & GGC TGC GAC A & $10-\mathrm{mer}$ & 70 & 41.2 \\
OPZ-9 & AGC AGC GCA C & 10-mer & 70 & 42.5 \\
\hline
\end{tabular}


total volume $25 \mu \mathrm{L}$. Primer RAPD yang digunakan adalah: OPA 18, OPZ 5, dan OPZ 9 (Tabel 1).

\section{Elektroforesis}

Sebanyak $5 \mu \mathrm{L}$ produk PCR yang sudah mengandung dye diamati dengan elektroforesis pada gel agarose $1,5 \%$ dan media $1 \mathrm{x}$ bufer TBE (Tris Borate EDTA). Running dilakukan menggunakan MUPID Gel Electrophoresis Unit pada voltase $100 \mathrm{~V}$ selama 45 menit dengan marker berukuran $100 \mathrm{bp}$ dan $1 \mathrm{kbp}$ sebagai standar berat molekul. Staining gel direndam dalam larutan SYBR safe selama 10 menit, lalu dibilas menggunakan akuades. Hasil PCR divisualisasikan pada UV transiluminator (AlphaImager Mini System, Proteinsimple)

\section{Analisis Data}

Jenis dan persentase kemunculan pola warna, persentase penutupan warna, serta profil warna digital strip hitam, putih, dan oranye dianalisis secara deskriptif menggunakan software Microsoft Excel 2007. Persentase penutupan warna ikan uji dibandingkan dengan ikan clown Biak populasi alam dan budidaya, strain black clownfish, platinum dan naked berdasarkan penelitian Kusumah et al. (2015). Perbedaan setiap persentase penutupan warna hitam, putih, dan oranye ikan uji dilakukan dengan uji-t pada $\mathrm{P}<0,05$ menggunakan software Microsoft Excel 2007. Secara genotipe, parameter yang diamati berupa profil fragmen DNA melalui pengamatan dan penghitungan langsung secara visual, serta heterozigositas dan
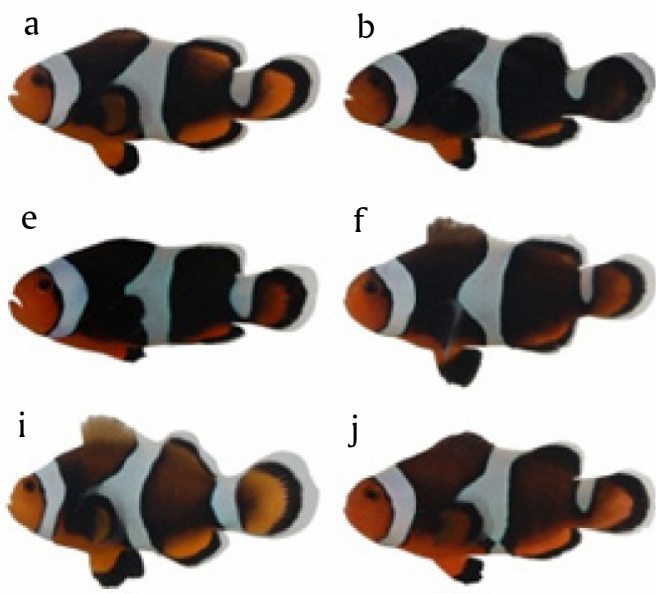
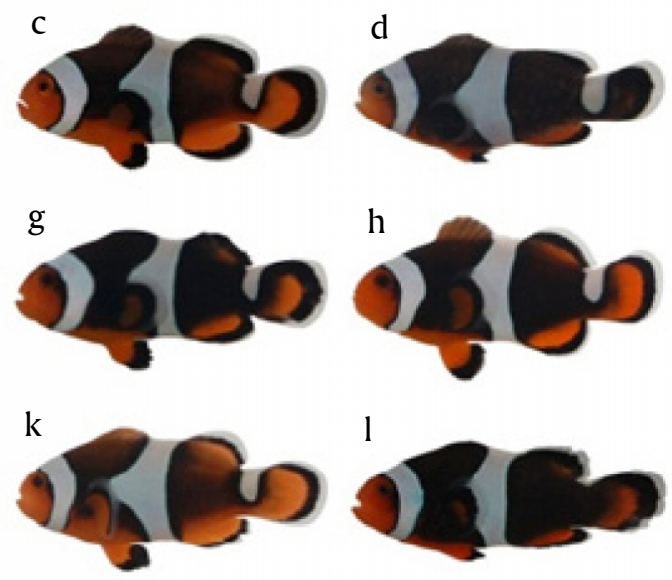

Gambar 2. Pola warna calon induk ikan clown strain black percula; (i) Sirip dada dominan oranye: a, c, g, h-k; (ii) sirip dada dominan hitam: b, d-f, l; (iii) sirip ekor dominan oranye: a, c, e-l; (iv) sirip ekor dominan hitam: b, d; (v) bentuk strip putih normal: a-h pada strip I dan II, I pada strip I, II, dan III, j pada strip I; (vi) bentuk strip putih terputus dan pelana: a-h, k pada strip III, j pada strip II dan III; (vii) bentuk strip putih hilang (misbar): I pada strip III; (viii) bentuk strip hitam III-IV terputus: i; (ix) bentuk strip hitam III-IV bergabung: a-h, j-l; (x) bentuk strip oranye III.6-IV.7 terputus: a, b, d- i, l; (xi) bentuk strip oranye III.6-IV.7 bergabung: c, j, k; (xii) kemunculan warna oranye 4, 5, 6, 7 titik: e, f, g, h

Figure 2. Color pattern of base broodstock of black percula clownfish strain. (i) pectoral fin dominan color of orange: $a, c, g, h$ - $k$; (ii) pectoral fin dominan color of black: $b, d$ $f$, l; (iii) caudal fin dominan color of orange: $a, c$, e-l; (iv) caudal fin dominan color of black: $b, d$; (v) normal shapes of white strip: $a-h$ on strip I and II, I on strip I, II, and III, $j$ on strip I; (vi) fragmented and saddle white strip shapes: $a-h, k$ on strip III, $j$ on strip II and III; (vii) absence of white strip shapes (misbar): I on strip III; (viii) fragmented black strip III-IV shapes: $i$; (ix) joining black strip III-IV shapes: $a$ $h$, j-l; (x) fragmented orange strip III.6-IV.7 shapes: $a, b, d-i, l$; (xi) joining orange strip III.6-IV.7 shapes: $c, j, k$; (xii) orange color presence on spots 4, 5, 6, 7: $e, f, g, h$ 
persentase polimorfisme dihitung menggunakan software TFPGA (Tools for Population Genetic Analysis) (Miller, 1997). Seluruh data dan informasi yang diperoleh selanjutnya ditampilkan dengan tabulasi dan grafik. Proses modifikasi grafik dilakukan dengan bantuan software Corel Draw X3 versi 13.0.0.576 (Corel Corporation, 2005).

\section{HASIL DAN BAHASAN}

\section{Keragaan Warna}

\section{Pola warna}

Pola warna ikan uji tampak bervariasi (Gambar 2). Variasi yang muncul berasal dari sirip dada (pectoral) dan sirip ekor (caudal) yang berwarna hitam atau oranye, strip hitam dan oranye antara bagian tubuh III dan IV yang bergabung atau terpisah, jumlah titik kemunculan warna oranye pada beberapa bagian tubuh, bentuk strip warna putih yang normal, terputus dan pelana, serta tanpa strip (misbar). Jika dibandingkan dengan laporan Kusumah et al. (2015), maka keragaan pola warna yang dimiliki ikan uji tampak kurang bervariasi terutama pada bentuk strip warna putih dan hitam. Pada penelitian Kusumah et al. (2015), pola warna ikan clown dikarakterisasi oleh strip hitam tebal, tipis, gelap, pudar, terputus (fragmented), bergabung (joining), serta strip putih berbentuk pelana (saddle), spot, terputus (fragmented), dan melebar, dengan variasi setiap karakter yang lebih beragam.

Tabel 2 menunjukkan persentase kemunculan setiap variasi pola warna ikan uji. Berdasarkan informasi tersebut, warna sirip ekor ikan uji secara umum didominasi oleh kehadiran warna oranye. Pada seluruh individu yang diamati, kehadiran strip warna

Tabel 2. Persentase kemunculan setiap variasi pola warna calon induk (F-0) clown black percula Table 2. Color pattern variations percentage of black percula clownfish broodstock F-0

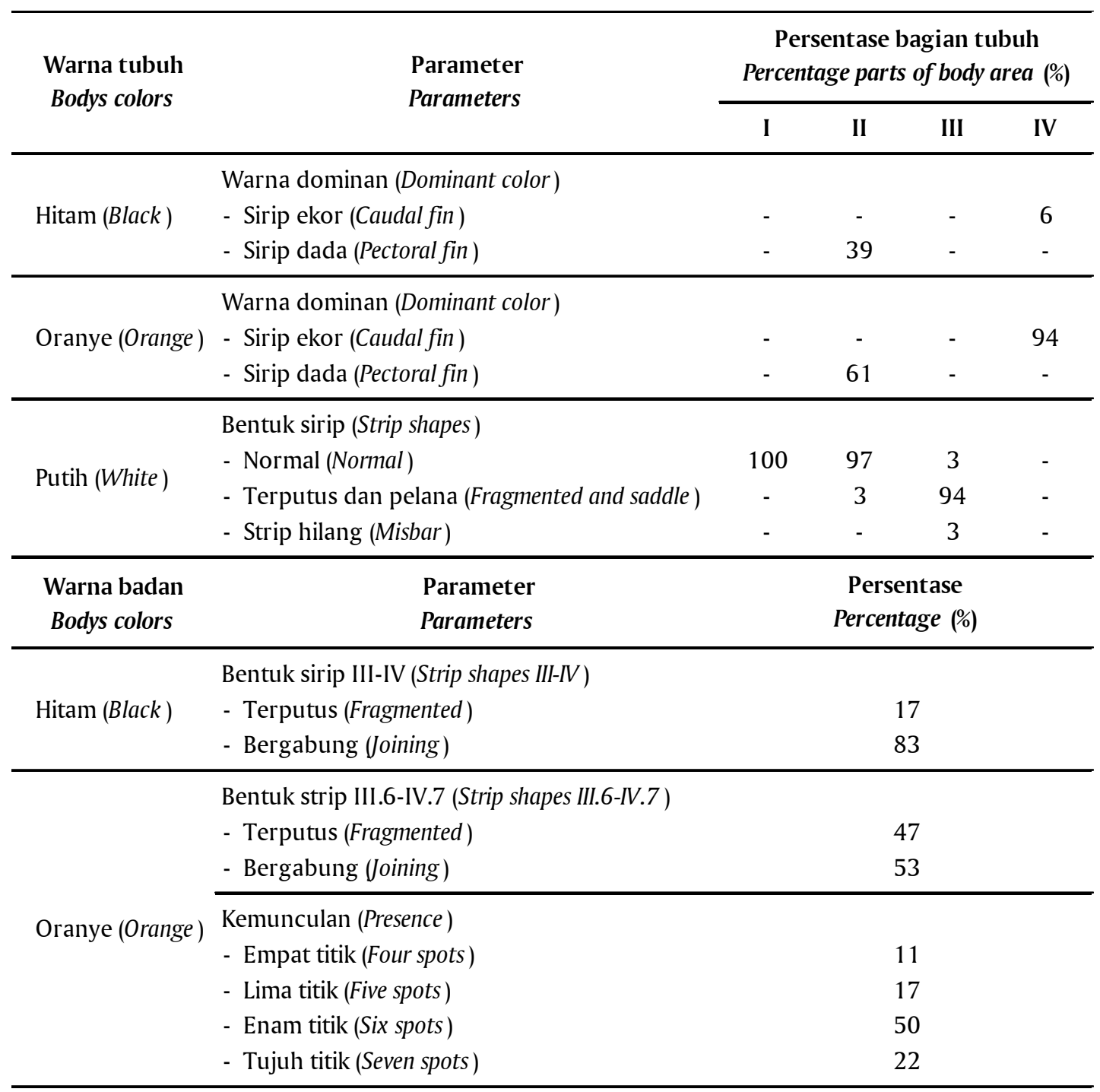


putih umumnya didominasi oleh bentuk normal pada bagian tubuh I dan II, serta bentuk terputus dan pelana pada bagian tubuh III. Variasi pola warna putih lainnya berasal dari garis putih yang menghilang (misbar) pada bagian tubuh III dengan persentase kemunculan yang rendah. Untuk pola warna hitam, variasi umumnya berasal dari bagian tubuh III.6-IV.7 yang didominasi bentuk strip yang bergabung antara kedua bagian tersebut, sedangkan untuk pola warna oranye, variasi umumnya berasal dari kehadiran enam titik warna oranye di beberapa bagian tubuh (Gambar 1) ikan uji (Gambar 2).

Pola warna pada ikan terbentuk dari adanya interaksi antara cahaya dengan pola distribusi sel warna (Cerda-Reverter et al., 2009). Terkait pembentukannya, Kelsh et al. (2004) menjabarkan tiga model/skenario pembentukan pola warna pada ikan. Skenario pertama, menyatakan bahwa (i) pola distribusi sel warna diduga terjadi karena adanya pengaruh sinyal dalam jangka waktu yang lama. Kedua, (ii) pola distribusi sel warna diduga terjadi karena adanya interaksi dengan jaringan-jaringan lokal (local tissues) seperti halnya sinyal lingkungan. Terakhir, (iii) pola distribusi sel warna diduga terjadi karena adanya interaksi lokal di antara sel warna yang berbeda (Kelsh et al., 2004).

Berdasarkan bentuknya, pola warna dibedakan menjadi empat bentuk dasar mulai dari (a) dorsal/ventral, (b) garis (strip) dan pita (bar), (c) tutul (spot), dan (d) polygon (contoh bentuk kebalikan dari spot) (Mills \& Patterson, 2009; Kondo \& Shirota, 2009). Pada ikan zebra (Danio rerio) pola warna ditunjukkan oleh bentuk strip yang horizontal, sedangkan pada spesies lainnya pola dibentuk oleh strip dan spot (D. nigrofasciatus), sedikit strip yang melebar (D. kerri), pola yang seragam (D. albolineatus), pita vertikal (D. choprae), dan pola strip dan spot yang lebih rumit (D. dangila) (Parichy, 2006).

Menurut Pederson (2015), setiap strain warna yang muncul pada ikan clown terjadi karena adanya pengurangan strip, strip yang melebar (over barring), strip yang solid (solid barring), bentuk spot, warna hitam di bawah putih, strip yang buram (smudgy barring), hingga adanya jenis warna albino. Berdasarkan hasil yang diperoleh, variasi pola warna ikan uji muncul dari pelebaran bentuk warna hitam pada sirip dada dan sirip ekor serta pengurangan strip dan bentuk warna putih dan oranye pada bagian tubuh II, III, dan

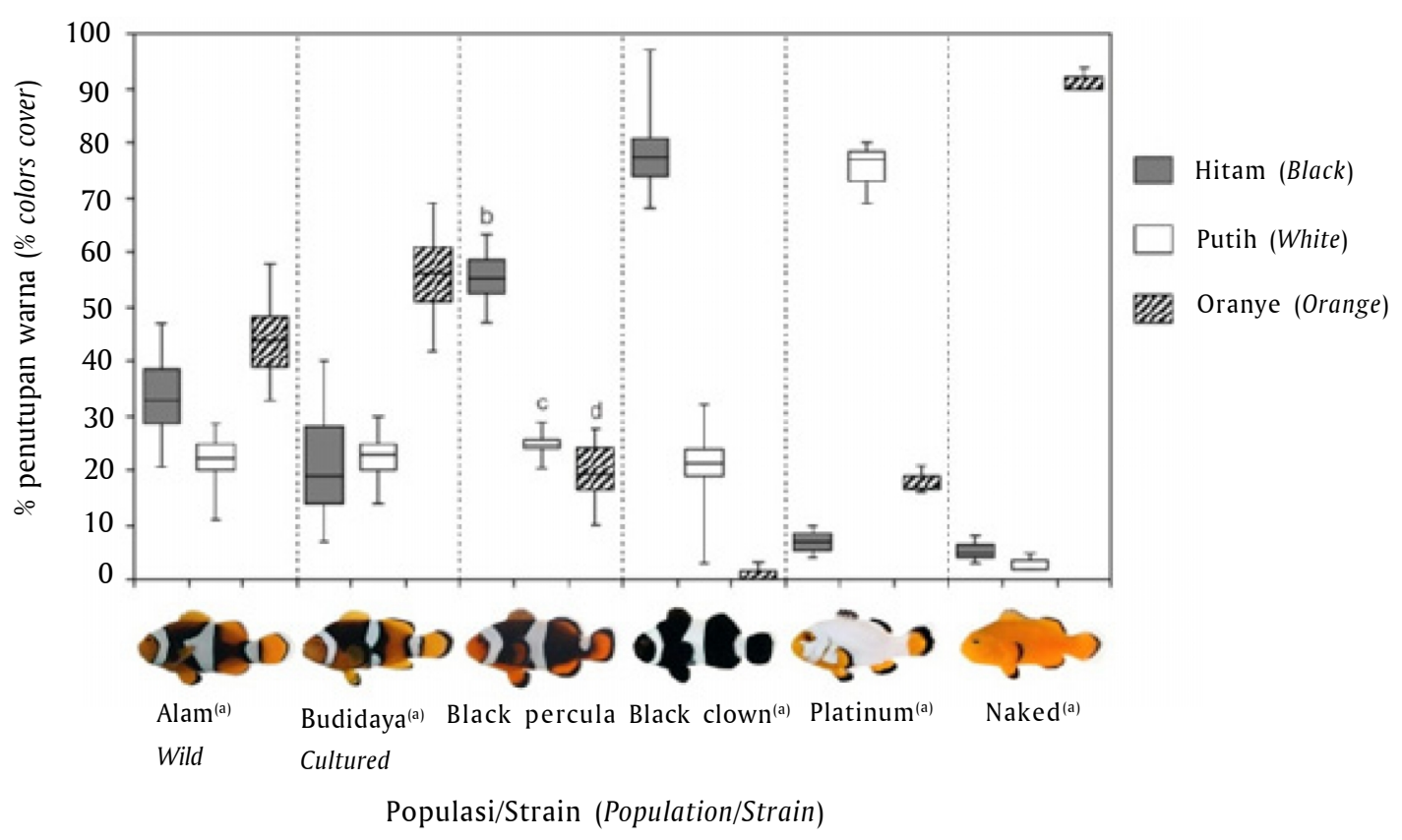

Gambar 3. Perbandingan persentase penutupan setiap jenis warna tubuh calon induk ikan clown strain black percula dengan populasi atau strain ikan clown lainnya (a: grafik diolah dari Kusumah et al. (2015); b, c, d: berbeda nyata, $\mathrm{P}<0,05$ )

Figure 3. Base broodstock of black percula clownfish color covering percentage with other populations or strains clownfishes (a: graphic modified from Kusumah et al. (2015); b, c, d: significantly different, $P<0.05$ ) 
IV (Gambar 2, Tabel 2). Pada bagian tubuh I, tidak tampak menunjukkan adanya variasi pola warna dimana pada bagian ini warna didominasi oleh penutupan warna oranye (Gambar 2).

\section{Persentase Penutupan Warna}

Selain pola warna, persentase penutupan warna juga merupakan salah satu karakter yang menjadi target dalam upaya pemuliaan ikan hias. Banyak strain warna dari spesies ikan hias diperoleh melalui upaya peningkatan atau pengurangan terhadap persentase penutupan suatu jenis warna tertentu, contoh ikan koi (Austin, 2008), guppy (Shaddock, 2012), cupang (IBC, 2007; Goldstein, 2004), dan mas koki (Smartt, 2001).

Gambar 3 menunjukkan status dan posisi persentase penutupan setiap jenis warna tubuh ikan uji dibandingkan dengan populasi dan/atau strain warna ikan clown lainnya berdasarkan laporan Kusumah et al. (2015). Ikan uji dikarakterisasi oleh persentase penutupan warna hitam yang cukup tinggi dan lebih spesifik (47\%-63\%) dibandingkan dengan kisaran nilai strain black clownfish yang lebih beragam. Persentase penutupan warna putih berada pada kisaran yang lebih sempit dan spesifik (20\%-29\%), sedangkan warna oranye berada pada kisaran nilai $10 \%-28 \%$. Pada strain black clownfish, persentase penutupan warna oranye dapat mendekati atau bahkan mencapai nilai $0 \%$, contoh strain midnight yang hanya dibentuk oleh satu jenis warna hitam pada seluruh permukaan tubuhnya (Sea \& Reef Aquaculture, 2016b). Berdasarkan penelitian yang dilakukan Kusumah et al. (2015) pada populasi alam dan budidaya ikan clown Biak ( $A$. percula), persentase penutupan warna tertinggi didominasi oleh warna oranye (Gambar 3).

Berdasarkan uji-t terhadap persentase penutupan warna, ketiga jenis warna yang dimiliki ikan uji menunjukkan perbedaan yang signifikan $(\mathrm{P}<0,05)$ antara satu sama lainnya (Gambar 3: b, c, d). Kondisi ini berarti bahwa luas area penutupan ketiga jenis warna yang dimiliki memang berbeda satu sama lainnya, meskipun jika dilihat dari grafik boxplot pada Gambar 3, persentase penutupan warna putih dan oranye masih memperlihatkan kisaran nilai yang saling tumpang tindih (overlapping).

Berdasarkan hasil yang diperoleh, variasi warna ikan uji menunjukkan ekspresi gen yang dinamis. Menurut Coliquehue \& Araneda (2014), terdapat beberapa gen yang diduga terlibat dalam perkembangan kromatofor, sintesis pigmen, dan ekspresi gen dalam produksi suatu jenis warna spesifik, serta pola warna, dimana jumlah gen tersebut tergantung pada jenis spesiesnya. Pada ikan zebra (Danio sp.) dan medaka (Oryzias sp.), masing-masing spesies memiliki 90 dan 40 gen yang mengontrol spesifikasi, proliferasi, sintasan, diferensiasi, dan distribusi kromatofor di antara proses-proses lainnya (Coliquehue \& Araneda, 2014). Pada ikan clown, beberapa gen diketahui mempengaruhi pigmentasi warna dan pola warna pada tubuh, sebagai contoh gen tyrosinase (Tyr) (Sembiring et al., 2013). Selain faktor genetika, menurut Dunham (2011), variasi pada penampilan fenotipe (VP) merupakan hasil perpaduan dari variasi genetika (VG), variasi lingkungan (VE), dan variasi yang dihasilkan dari interaksi antara genetika dan lingkungan (VGE) atau dapat diformulasikan dengan rumus: $V P=V G+V E+V G E$.

\section{Jenis warna}

Jenis warna menggambarkan profil atau spesifikasi suatu karakter warna tertentu. Warna bersifat kualitatif, sehingga seringkali pengamat memiliki persepsi yang berbeda akan suatu jenis warna yang dilihatnya (subjektif), contoh merah sangat terang, terang, agak gelap, sedikit gelap, gelap, dan sangat gelap. Pengamatan jenis warna melalui analisa gambar digital menjadi solusi yang memberikan penilaian objektif terhadap suatu jenis warna tertentu melalui penjelasan secara kuantitatif pada suatu nilai digital warna. Jenis warna dapat ditampilkan melalui grafik, sehingga nilai digital warna yang terukur dapat dipahami dengan lebih mudah.

Gambar 4 menunjukkan profil warna digital ikan uji. Berdasarkan gambar tersebut, warna oranye tubuh calon induk memiliki kisaran nilai Hue yang lebih sempit dan cenderung stabil dibandingkan ikan clown Biak yang berasal dari populasi alam dan budidaya yang masing-masing berkisar antara $15-37^{\circ}$ dan $15-40^{\circ}$ (Kusumah et al., 2015). Warna yang terlihat tampak lebih oranye dikarenakan posisinya yang bergerak ke arah warna digital merah pada model warna HSB (Gambar 4). Kondisi yang sama juga terjadi ketika warna oranye ikan uji (Gambar 4) dibandingkan dengan spesies A. ocellaris yang memiliki nilai hue berkisar 31-36 (Yasir \& Qin, 2009; 2010). Warna yang lebih oranye diduga muncul karena adanya dukungan serta asosiasi dengan warna dasar tubuh yang gelap dari ikan uji sehingga warna yang terlihat tampak lebih kontras. Berdasarkan parameter saturation, ikan uji memiliki persentase saturasi yang lebih rendah dengan variasi yang lebih beragam dibandingkan populasi ikan clown Biak alam dan budidaya (Kusumah et al. (2015). Berdasarkan parameter brightness sebaran data yang dihasilkan menunjukkan variasi yang kurang beragam dibandingkan hasil penelitian Kusumah et al. (2015).

Pada jenis warna putih, kisaran nilai hue menunjukkan variasi yang lebih beragam dibandingkan dengan ikan clown Biak populasi alam dan budidaya 


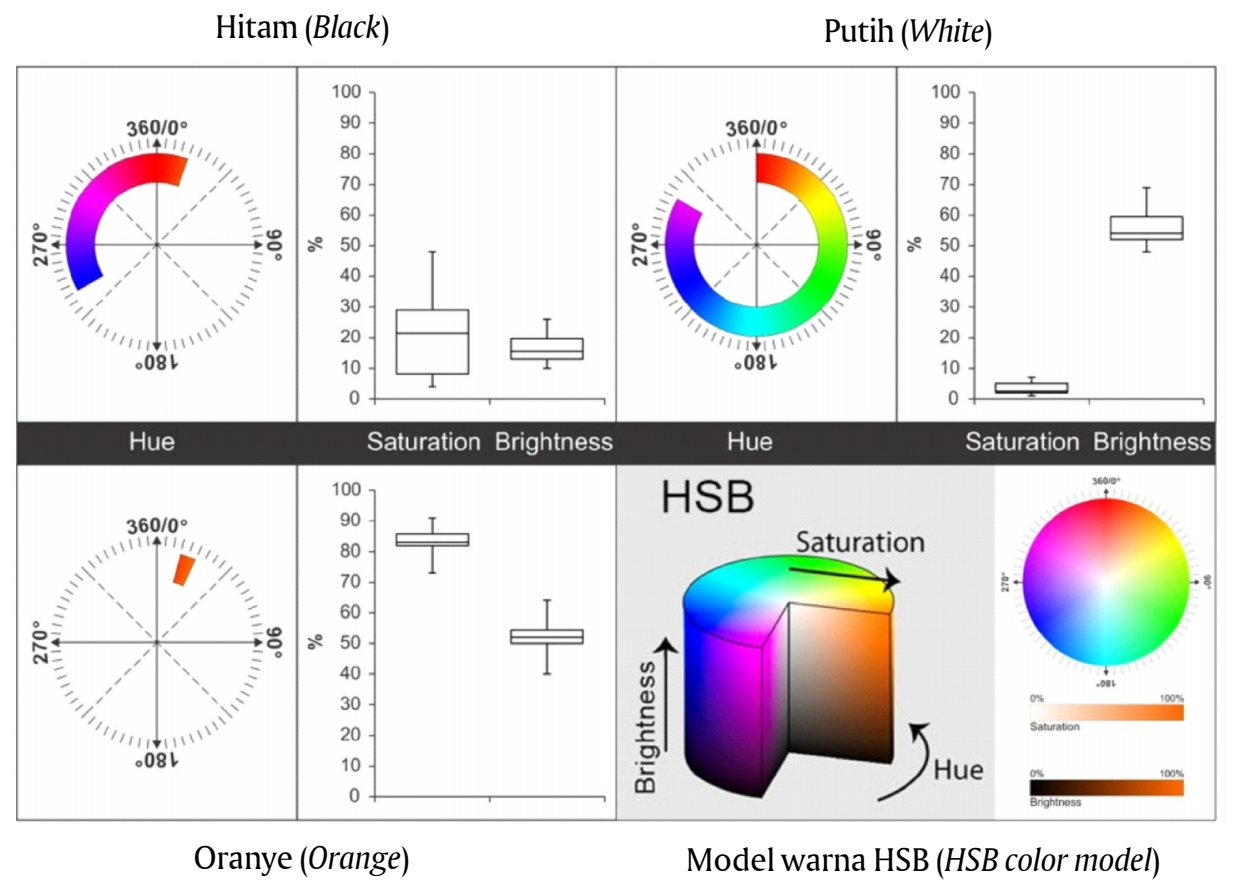

Gambar 4. Profil warna digital calon induk (F-0) ikan clown strain black percula

Figure 4. Digital color profile of black percula clownfish broostock F-0

(Kusumah et al., 2015). Berdasarkan nilai saturasinya, warna putih pada ikan uji tampak memiliki kisaran yang menyerupai dengan populasi alam dan budidaya ikan clown Biak (Kusumah et al., 2015). Menurut nilai brightness-nya, ikan uji tampak memiliki nilai yang lebih rendah dibandingkan hasil penelitian Kusumah et al. (2015).

Kisaran nilai Hue warna hitam ikan uji tampak memiliki variasi yang lebih beragam dibandingkan ikan clown Biak populasi alam dan budidaya (Kusumah et al., 2015). Jika diterjemahkan dalam model warna HSB, warna hitam ikan uji berada pada rentang warna biru hingga oranye. Berdasarkan nilai saturation, tampak menunjukkan rentang yang bervariasi. Jika dibandingkan dengan populasi alam dan budidaya ikan clown Biak, nilai yang diperoleh tampak lebih menyerupai populasi budidaya. Berdasarkan parameter brightness, nilai ikan uji yang diperoleh cenderung lebih tinggi dibandingkan populasi alam dan budidaya (Kusumah et al., 2015).

Warna pada hewan berasal dari sel warna (kromatofor) yang terbagi menjadi dua golongan, yaitu (i) golongan yang menyerap cahaya (lightabsorbing chromatophore): melanophore; erythropore; xanthophore; dan cyanophore; serta (ii) golongan yang memantulkan cahaya (light-reflecting chromatophore): leucophore dan iridophore (Fujii, 2000; Kelsh, 2004; Leclercq et al., 2009). Warna hitam, kuning-oranye, dan putih pada ikan masing-masing dihasilkan dari sel warna melanophore, xanthophore-erythropore, dan leucophore di mana kualitas warna yang muncul secara fenotipe dapat dipengaruhi oleh kualitas air (Lin et al., 2009), kondisi pemeliharaan (Van der Salm et al., 2003), cahaya (Yasir \& Qin, 2009), warna wadah pemeliharaan (Doolan et al., 2008; Turne et al., 2009), hingga nutrisi (Kalinowski et al., 2007; Yasir \& Qin, 2010).

\section{Keragaan Genotipe}

Gambar 5 merupakan tampilan fragmen DNA hasil elektroforesis pada ikan uji berdasarkan hasil amplifikasi menggunakan primer OPA 18, OPZ 5, dan OPZ 9. Berdasarkan hasil tersebut, terlihat variasi genetika dari setiap individu yang dianalisis.

\section{Profil Fragmen DNA}

Tabel 3 menunjukkan ukuran dan jumlah fragmen, heterozigositas, serta derajat polimorfisme ikan uji. Rentang ukuran fragmen ikan uji terpanjang berasal dari hasil amplifikasi oleh primer OPZ 5 dan terpendek berasal dari primer OPZ 9. Jika dibandingkan dengan spesies $A$. percula, ukuran fragmen ikan uji berada dalam kisaran penelitian Prasetio et al. (2014) namun memiliki ukuran yang lebih pendek pada lokus OPA 18 dan OPZ 5, serta memiliki kisaran yang sedikit berbeda pada lokus OPZ 9. Ukuran fragmen OPA 18, OPZ 9, dan OPZ 5 ikan clown A. percula masing-masing berada pada kisaran 100-4700 bp, 100-2300 bp, dan 300-4800 bp (Prasetio et al., 2014). 


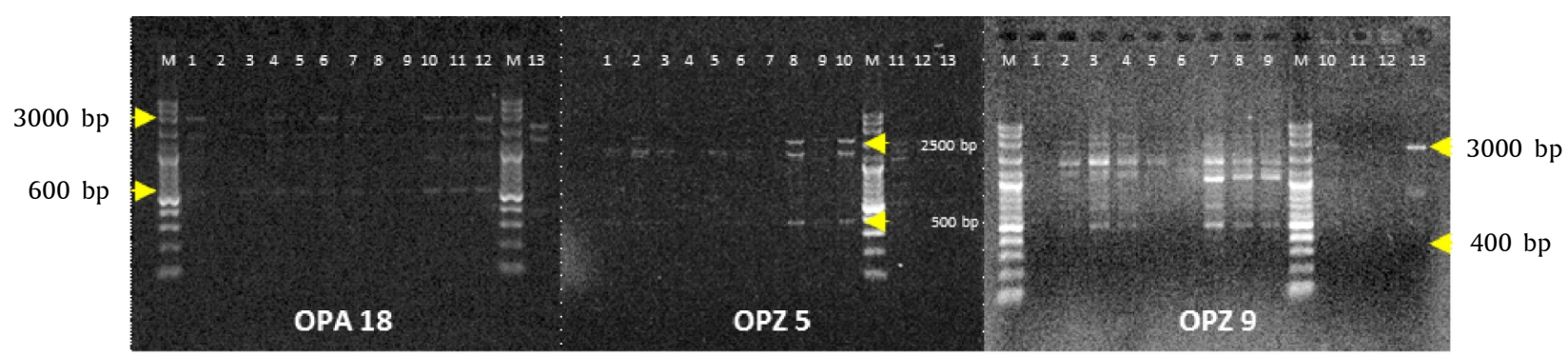

Gambar 5. Tampilan fragmen DNA produk PCR-RAPD menggunakan primer berbeda (M: size marker, 1-13: nomor sampel, OPA-18, OPZ-5, OPZ-9: primer)

Figure 5. DNA fragments of RAPD-PCR products (M: size marker, 1-13: samples numbers, OPA-18, OPZ-5, OPZ-9: primers)

Berdasarkan jumlah total fragmennya, ikan uji memiliki jumlah fragmen OPA 18, OPZ 9, dan OPZ 5 yang cenderung lebih sedikit dibandingkan hasil penelitian Prasetio et al. (2014) yang mengkaji populasi alam dan budidaya ikan clown Biak. Dengan jenis primer yang sama, jumlah fragmen yang dihasilkan masing-masing primer dapat mencapai 5 fragmen, 9 fragmen, dan 9 fragmen (Prasetio et al., 2014).

Hasil analisis pada Gambar 2 memperlihatkan bahwa populasi alam ikan clown Biak memiliki persentase penutupan warna hitam berkisar $21 \%-47 \%$, populasi budidaya $7 \%-40 \%$, sedangkan ikan uji menunjukkan nilai sebesar $47 \%-63 \%$. Jika persentase nilai tersebut (Gambar 2) kemudian dikaitkan dengan jumlah fragmen RAPD yang dihasilkan pada Tabel 3 dan dibandingkan dengan Prasetio et al. (2014) pada populasi alam dan budidaya, maka persentase penutupan warna hitam tampak menunjukkan hubungan yang berbanding terbalik dengan jumlah fragmen DNA yang dihasilkan. Hal yang sama juga dilaporkan Kusumah et al. (2016) yang mengkaji variasi genetika setiap selang kelas persentase penutupan warna hitam $A$. percula. Berdasarkan laporan tersebut, diketahui bahwa keragaman genetika ikan clown Biak menunjukkan trend yang semakin meningkat seiring penurunan persentase penutupan warna (Kusumah et al., 2016).

\section{Keragaman Genetik}

Polimorfisme dan heterozigositas menunjukkan potensi kemampuan adaptasi terhadap lingkungannya, karena semakin tinggi heterozigositas maka semakin banyak pula gen yang terlibat dalam menyumbangkan tingkat kebugaran suatu populasi (Soewardi, 2007). Derajat polimorfisme menggambarkan ukuran keragaman genetika intrapopulasi yang didasarkan pada besarnya populasi lokus polimorfik terhadap total lokus yang diidentifikasi. Berdasarkan derajat polimorfisme, populasi ikan uji memiliki nilai yang cukup tinggi (Tabel 3). Namun jika dibandingkan dengan $A$. percula alam yang bernilai $97,82 \%$ (Prasetio et al., 2014), nilai polimorfisme tersebut lebih rendah. Akan tetapi, jika dibandingkan dengan populasi budidaya yang bernilai 41,3\% (Prasetio et al., 2014), derajat polimorfisme populasi ikan uji adalah lebih tinggi.

Heterozigositas menggambarkan jumlah individu heterozigot pada lokus tertentu di dalam populasi. Berdasarkan Tabel 3, nilai heterozigositas ikan uji secara total lebih tinggi dibandingkan nilai heterozigositas $A$. percula alam dan budidaya yang masing-masingnya bernilai 0,1471 dan 0,1000 (Prasetio et al., 2014). Jika dibandingkan dengan penelitian Sembiring et al. (2013) pada A. ocellaris, nilai

Tabel 3. Keragaan genotipe calon induk (F-0) ikan clown strain black percula

Table 3. Genotype performance of of black percula clownfish broostock F-0

\begin{tabular}{|c|c|c|c|c|c|c|c|}
\hline \multicolumn{3}{|c|}{$\begin{array}{l}\text { Ukuran fragmen } \\
\text { Fragment size (bp) }\end{array}$} & \multicolumn{3}{|c|}{$\begin{array}{l}\text { Jumlah fragmen } \\
\text { Fragment count }\end{array}$} & \multirow{2}{*}{$\begin{array}{l}\text { Heterozigositas } \\
\text { Heterozigosity }\end{array}$} & \multirow{2}{*}{$\begin{array}{c}\text { Persentase } \\
\text { polimorfisme } \\
\text { Percentage } \\
\text { polimorphism (\%) }\end{array}$} \\
\hline OPA-18 & OPZ -9 & OPZ-5 & OPA-18 & OPZ -9 & OPZ-5 & & \\
\hline $600-3,000$ & $500-2,500$ & $400-3,000$ & 3 & 5 & 3 & 0.3060 & 88 \\
\hline
\end{tabular}


heterozigositas ikan uji lebih rendah. Menurut Kurniawirawan (2007), tinggi rendahnya nilai heterozigositas terkait dengan inbreeding. Semakin rendah nilai heterozigositas, maka diduga telah terjadi inbreeding tinggi yang akan menyebabkan rendahnya variasi gen yang terbentuk untuk menimbulkan suatu gen spesifik.

\section{Pengembangan Strain Black Percula}

Berdasarkan kajian yang dilakukan, baik pada keragaan fenotipe warna maupun genotipe, ikan uji menunjukkan variasi yang beragam. Sebagai contoh pada karakter pola warna yang memiliki 18 variasi (Tabel 2) begitu juga pada persentase penutupan warna (Gambar 3).

Breeding program berupa selektif breeding diperlukan sebagai upaya meningkatkan persentase penutupan warna hitam pada ikan clown strain black percula. Berdasarkan Gambar 3, calon induk black percula masih memiliki persentase penutupan warna hitam berkisar antara 47\%-63\%. Jika target yang diinginkan seperti halnya strain black clownfish (Gambar 3) yang memiliki persentase penutupan warna hitam yang berkisar 68\%-97\% dan warna oranye yang mendekati 0\% (Kusumah et al., 2015) maka masih diperlukan upaya selektif breeding pada calon induk yang dimiliki.

Upaya lainnya yang juga dapat ditempuh adalah dengan cara menyilangkan (hibrid) calon induk strain black percula secara langsung dengan strain black clownfish. Generasi anakan dengan persentase hitam tinggi yang diperoleh kemudian dikawinkan kembali dengan induknya (backcross). Pada ikan hias, contoh ikan cupang (Betta splendens), upaya ini seringkali dilakukan untuk "mengunci" suatu karakter yang diinginkan, seperti halnya pada pembentukan strain dragon (Stark-Parnell \& van Esch, 2009).

Pada kasus lainnya, breeding program yang dilakukan pada ikan hias juga ditempuh melalui jalur inbreeding (perkawinan sekerabat), contoh ikan guppy (Bleakley et al., 2008), agar memperoleh populasi homogeni, maupun melalui crossbreeding dengan populasi/spesies yang memiliki keragaman genetika berbeda atau jarak genetika yang jauh untuk mendapatkan suatu karakter unik tertentu, contoh persilangan antara ikan tiger catfish (Pseudoplatystoma spp.) dengan redtail catfish (Phractocephalus hemioliopterus) (Monster Fish Keepers, 2012) yang menghasilkan strain leopard catfish (Fish Forums, 2011).

Pada ikan clown, upaya persilangan telah dilakukan dengan cara menyilangkan $A$. percula dengan $A$. ocellaris untuk menghasilkan strain Black Photon yang memiliki persentase penutupan warna hitam tinggi (Joshi, 2011;
Sea \& Reef Aquaculture, 2016c). Setelah memperoleh persentase penutupan hitam yang tinggi, breeding program calon induk dapat dilanjutkan untuk mendapatkan pola warna putih yang unik, contoh daVinci, picasso, snowflake, froshbite, domino, dan lainnya (ORA Farm, 2014a; 2014b; Barrier Reef Aquariums, 2016; Sea \& Reef Aquaculture, 2016a).

\section{KESIMPULAN}

Keragaan fenotipe warna tubuh calon induk (F0) ikan clown strain black percula menunjukkan variasi pola warna yang cukup beragam, persentase penutupan warna tubuh didominasi oleh hitam yang tinggi, dan jenis warna digital hitam yang gelap; putih yang terang; dan oranye yang lebih kontras. Berdasarkan keragaan genotipenya, calon induk ikan clown strain black percula memiliki keragaman genetika yang cukup tinggi. Untuk mendapatkan strain warna black percula yang diinginkan, diperlukan tahap seleksi lebih lanjut untuk meningkatkan persentase penutupan warna hitam serta memperoleh suatu pola warna putih yang unik.

\section{UCAPAN TERIMA KASIH}

Penulis mengucapkan terima kasih kepada Bapak Doni dari BPBLAmbon atas bantuan dalam memperoleh sampel. Secara khusus, penulis juga mengucapkan terima kasih kepada Bapak Nian dari Balai Penelitian dan Pengembangan Budidaya Ikan Hias Depok atas bantuan teknis pelaksanaan penelitian. Penelitian ini dibiayai oleh DIPA Tahun Anggaran 2015.

\section{DAFTAR ACUAN}

Austin, S. (2008). Garyu koi farm. Koi Carp, p. 47-50. Barrier Reef Aquariums. (2016). Clownfish. Diakses dari http://www. barrierreefaquariums.com/ productcart/pc/Clownfish-c96.htm

Bleakley, B.H., Eklund, A.C., \& Brodie, E.D. (2008). Are designer guppies inbred? Microsatellite variation in five strains of ornamental guppies, Poecilia reticulata, used for behavioral research. Zebrafish, 5(1), 39-48. doi:10.1089/zeb. 2007.0513

Cerda-Reverter, J. M., Haitina, T., Schioth, H. B., \& Peter, R. E. (2009). Gene Structure of the Goldfish Agouti-Signaling Protein: A Putative Role in the Dorsal-Ventral Pigment Pattern of Fish. Endocrinology, 146(3), 1597-1610. doi:10. 1210/en.20041346.

Colihueque, N., \& Araneda, C. (2014). Appearance traits in fish farming: progress from classical genetics to genomics, providing insight into current and potential genetic improvement. Frontiers in Genetics, 5(251), 1-8. doi:10.3389/fgene.2014. 00251. 
Dunham, R.A. (2011). Aquaculture and fisheries biotechnology: Genetic approaches. 2nd Edition. Cambridge, US: CABI Pub.

Doolan, B.J., Allan, G.L., Booth, M.A., \& Jones, P.L. (2008). Effects of cage netting colour and density on the skin pigmentation and stress response of Australian snapper Pagrus auratus (Bloch \& Schneider, 1801). Aquaculture Research, 39, 13601368. doi:10.1111/j.1365-2109.2008.02003.x.

Fujii, R. (2000). The Regulation of motile activity in fish chromatophores: Review. Pigment Cell \& Melanoma Research, 13, 300-319. doi:10.1034/j.16000749.2000.130502.x.

Fish Forums. (2011) Pseudoplatystoma fasciatum x Phrac tocephalus hemioliopterus [Online forum comment]. Diakses, dari http://www.fishforums.net/ index.php?/topic/372165-pseudoplatystomaf a s c i a t u m - x - p h r a c t o c e p halus hemioliopterus/tanggal 5 September.

Goldstein, R.J. (2004). The betta handbook. Hauppauge, NY: Barron's.

IBC. (2007). IBC exhibition standards. Revised 7/15/ 2007. International Betta Congress.

Joshi, S. (2011). Photon clownfish genetics - a tale of a promiscuous female onyx percula. Diakses dari https://reefs.com/2011/ 09/27/photonclownfish-genetics-a-tale-of-a-promiscuous-female-onyx-percula/, tanggal 27 September.

Kalinowski, C.T., Izquierdo, M.S., Schuchardt, D., \& Robaina, L.E. (2007). Dietary supplementation time with shrimp shell meal on red porgy (Pagrus pagrus) skin colour and carotenoid concentration. Aquaculture, 272, 451-457. doi:10.1016/ j.aquaculture.2007.06.008.

Kelsh, R.M. (2004). Genetics and evolution of pigment patterns in fish - review: pigment gene focus. Pigment Cell \& Melanoma Research, 17, 326336. doi:10.1111/j.1600-0749.2004.00174.x.

Kondo, S., \& Shirota, H. (2009). Theoretical analysis of mechanisms that generate the pigmentation pattern of animals: Review. Seminars in Cell \& Developmental Biology, 20, 82-89. doi:10.1016/ j.semcdb.2008.10.008

Kurniawirawan, A. (2007). Analisis keragaman genetik beberapa populasi ikan batak (Tor soro) dengan metode Random Amplified Polymorphism DNA (RAPD). Skripsi. Institut Pertanian Bogor. Bogor, Unpublished.

Kusumah, R.V., Kusrini, E., Murniasih, S., Prasetio, A.B., \& Mahfudz, K. (2011). Analisis gambar digital sebagai metode karakterisasi dan kuantifikasi warna pada ikan hias. J. Ris. Akuakultur, 6(3), 381-392.
Kusumah, R.V., Cindelaras, S., \& Prasetio, A.B. (2015). Keragaan warna ikan clown Biak (Amphiprion percula) populasi alam dan budidaya berdasarkan analisis gambar digital.J. Ris. Akuakultur, 10(3), 345355.

Kusumah, R. V., Prasetio, A. B., Kusrini, E., \& Ardi, I. (2016). Keragaman genetika penutupan warna hitam ikan clown Biak (Amphiprion percula) berdasarkan metode RAPD. Naskah telah diajukan untuk publikasi.

Leclercq, E., Taylor, J.F., \& Migaud, H. (2009). Morphological skin colour changes in teleosts. Fish And Fisheries, 11(2), 1-35. doi:10.1111/j.14672979.2009.00346.x.

Lin, Q., Lin, J., \& Huang, L. (2009). Effects of substrate color, light intensity and temperature on survival and skin color change of juvenile seahorses, Hippocampus erectus Perry, 1810. Aquaculture, 298, 157-161. doi:10.1016/j. aquaculture.2009.10.015.

Miller, M.P. (1997). TFPGA Version 1.3. A Windows program for the analysis of allozyme and molecular population genetic data [Software komputer]. Diakses dari http:// www.marksgeneticsoftware.net/tfpga.htm.

Mills, M.G. \& Patterson, L.B. (2009). Not just black and white: Pigment pattern development and evolution in vertebrates. Seminars in Cell \& Developmental Biology, 20, 72-81. doi:10.1016/ j.semcdb.2008.11.012.

Monster Fish Keepers. (2012). Hybrid catfish discussion thread. [Online forum comment]. Diakses dari http://www.monsterfishkeepers.com/ forums/ threads/hybrid-catfish-discussion-thread.509052/ page-11, tanggal 28 Desember.

ORA Farm. (2014a). ORA domino (Amphiprion ocellaris). Diakses dari http:/www.orafarm.com/products/ fish/clowns/domino/, tanggal 31 Desember.

ORA Farm. (2014b). ORA naked ocellaris (Amphiprion ocellaris). Diakses dari http://www.orafarm.com/ products/fish/clowns/naked/, tanggal, 31 Desember.

Parichy, D.M. (2006). Evolution of danio pigment pattern development. Heredity, 97, 200-210. doi:10.1038/sj.hdy.6800867.

Pederson, M. (2015). Part 2: Genetics; Clownfish. Wilkerson's Lost Chapters. Diakses dari https:// prezi.com/fhcsu1p_2fzt/part-2-genetics-clownfish wilkersons-lost-chapters/, tanggal, 22 April.

Permen KP Tentang Jenis Baru Ikan yang akan Dibudidayakan. (2014). Kementerian Kelautan dan Perikanan. Jakarta.

Prasetio, A.B., Kusumah, R.V., Cindelaras, S., Hayuningtyas, E.P., Rahmawati, R., \& Kusrini, E. 
(2014). Evaluasi kualitas fenotipe dan genotipe ikan hias clown Biak (Amphiprion sp.) hasil budidaya. Laporan Seminar Hasil Balai Penelitian dan Pengembangan Budidaya Ikan Hias, Depok. Jawa Barat.

Rasband, W. (2016). ImageJ: Image processing and analysis in Java. [Software komputer]. Diakses dari http://imagej.nih.gov/ij/

Saltwater Fish. (2016). Ora black \& white false perculaaquacultured - misbar. Diakses dari http:// www.saltwaterfish.com/product-ora-black-whitefalse-percula-aquacultured-misbar, tanggal 21 Juli.

Sea \& Reef Aquaculture. (2016a). New sea \& reef strain. Diakses dari http://www.seaandreef.com/ marine-ornamental-fish/clownfish/black-davinciclownfish, tanggal 5 Februari.

Sea \& Reef Aquaculture. (2016b). Midnight. Diakses dari http://www.seaandreef.com/marine-ornamental-fish/clownfish/midnight, tanggal 5 Februari.

Sea \& Reef Aquaculture. (2016c). Black-photon. Diakses dari http:/www.seaandreef.com/marineornamental-fish/clownfish/black-photon, tanggal 5 Februari.

Sembiring, S.B.M., Setiawati, K.M., Hutapea, J.H. \& Subamia, W. (2013). Pewarisan Pola Warna Ikan Klon Biak, Amphiprion percula. Jurnal Ilmu dan Teknologi Kelautan Tropis, 5(2), 343-351.

Shaddock, P. (2012). Guppy color strains third edition. [Adobe Digital Editions version]. Diakses dari https://www.scribd.com/doc/252779601/ Guppy-Color-Strains-Philip-Shaddock.
Smartt, J. (2001). Goldfish varieties and genetics: A handbook for breeders. Oxford: Blackwell Science.

Soewardi, K. (2007). Pengelolaan keragaman genetik sumberdata perikanan dan kelautan. Institut Pertanian Bogor.

Stark-Parnell, V., \& Van Esch, J. H. M. (2009). November/December). "Dragons" - A new era in the world of "bling-bling" bettas! Flare!, 43(3).

Turne, R.K., Sikes, A.L., Tabrett, S., \& Smith, D.M. (2009). Effect of background colour on the distribution of astaxanthin in black tiger prawn (Penaeus monodon): effective method for improvement of cooked colour. Aquaculture, 296, 129-135. doi:10.1016/j.aquaculture.2009.08.006.

Van der Salm, A.L., Martinez, M., Flik, G., \& Bonga. S.E.W. (2003). Effects of husbandry conditions on the skin colour and stress response of red porgy, Pagrus pagrus. Aquaculture, 231, 371-386. doi:10.1016/j.aquaculture.2004.08.038.

Yasir, I., \& Qin, J.G. (2009). Effect of light intensity on color performance of false clownfish, Amphiprion ocellaris Cuvier. Journal of the World Aquaculture Society, 30(3), 337-350. doi:10.1111/j.17497345.2009.00254.x.

Yasir, I., \& Qin, J.G. (2010). Effect of dietary carotenoids on skin color and pigments of false clownfish, Amphiprion ocellaris Cuvier.Journal of the World Aquaculture Society, 31(3), 308-318. doi:10.1111/j.1749-7345.2010.00373.x. 